\title{
The Effect of Front-of-Package Traffic Light (FoPTL) Nutrition Label Design on the Acceptability and Understanding of Nutrition Labels for Hypertension Patients
}

\author{
Ainy Sucianti ${ }^{1}$ and Fatmah ${ }^{1 *}$ \\ ${ }^{\text {I}}$ Public Health Nutrition Dept., Faculty of Public Health, Universitas Indonesia, Depok 16424, West Java \\ Province, Indonesia
}

Corresponding Authors’Email: *ffatmah@yahoo.com

\begin{abstract}
The practice of reading nutrition labels and understanding the information still remains low in Indonesia, especially among hypertensive patients. Yet, Front-of-Package Traffic Light (FoPTL) labels can be well received by the community compared to information labels that display nutritional values. Hypertension sufferers need to understand such FoP-TL labels in order to be aware of their sodium consumption and not exceed recommended limits. The purpose of this study was to assess the effect of nutrition label designs on acceptance and understanding among hypertensive patients. The quasi-experimental study design was applied over a period of three weeks, with a control group containing 11 subjects (nutritional value information labels) and an intervention group comprising 10 subjects (FoP-TL labels) selected by purposive sampling. The collection of primary data at the beginning of the study included data on the subjects' characteristics (age, education, income, weight, height, BMI and blood pressure), knowledge of nutrition and health, their behaviour relating to the reading of nutritional value information labels, and their understanding of nutrition labels and perceptions of their attractiveness. In the first week, the subjects were given a pre-test on nutrition labels with the help of a dummy, aimed at determining their understanding of nutritional value information labels. During the second week, education was provided in the form of different booklets and dummies according to each group, while in the third week a post-test was administered to measure the effects of the nutrition labels received by both groups. The results showed significant differences in terms of the increase in understanding between the control and intervention groups (22.15 points in control group and 34.3 points in intervention group), while there were also differences in the average acceptability scores for both groups (47.7 points in control group and 55.7 points in intervention group. FoP-TL labels can thus be used to understand what constitutes good nutrition labels for use with hypertensive patients.
\end{abstract}

Keywords: Hypertension, Front-of-Package Traffic Light, nutrition labelling understanding, acceptance

\section{Introduction}

An examination of nutrition labels prior to the purchasing of packaged foods can be used by people as a means of assessing the nutritional content of such foods and can thus help members of the community to select the right foods (Nelson et al, 2014; Campos et al., 2011; Gupta and Dharni, 2016; FDA, 2016). Improving the habit of reading food packaging labels that display information on nutritional value can be an effective way of improving good eating habits and working towards the prevention of certain chronic diseases related to poor eating habits (Post et al., 2010; Gupta and Dharni, 2016), such as hypertension, heart disease and diabetes (FDA, 2014). The greatest impact of 
reading food packaging labels can be observed when consumers consider sugar, salt and saturated fat content before buying and consuming packaged foods (Helfer and Shultz, 2014).

The results of a study by the National Consumer Protection Agency showed that only $6.7 \%$ of people read the nutrition labels on foods (BPKN, 2007). This is very low considering the frequency with which packaged foods are purchased by the community, which has increased from $35 \%$ to 47\% (Deloitte, 2016). Moreover, even consumers who read labels do not properly understanding the information they contain. This is because such nutrition labels contain a surplus of information that people find difficult to understand (Jacobs et al, 2010). What we know about consumers reading nutrition labels is consistent with the finding that the nutritional knowledge of consumers continues to be low (Zahara and Triyanti 2009; Palupi et al, 2017; Themba and Tanjo, 2013; Williams and Mummery, 2012).

People prefer labels that are simple and easy to understand (Feunekesa et al, 2008; Kees et al, 2014; Julia et al., 2015). Simple labels require less in the way of effort to digest and time to understand compared to more detailed labels (Andrews et al., 2011; Azman and Sahak, 2014). The use of an attractive design for nutrition labels can also motivate people to read them (Ranilovic and Baric, 2011). Therefore, various efforts have been made to provide convenience to consumers. One such example is the front-of-packaging (Front of Pack - FoP) label developed by the UK Food Standards Agency (FSA) that uses a traffic light (Front-of-Package Traffic Light-FoP-TL) format. This system of traffic-light labelling can make it easier for people to understand the nutritional content of packaged foods (McLean et al, 2012; Mohan et al, 2009; Me'jean et al, 2014; Hodgkins et al, 2015; Regan et al, 2016).

FoP-TL labelling was created with the aim of supplementing nutritional value information labels and as a means of overcoming their limitations in attracting public attention (Roberto and Khandpur, 2014). The advantages of FOP-TL labelling include its use of a colour system to indicate the nutritional content of packaged foods, rather than the numerical information-based format of nutritional value information labels (Roberto and Khandpur, 2014). Some studies have found that FOP-TL labelling is well received by the public and is easier to understand than labels displaying nutritional value information (Edge et al, 2014). Research in Europe shows that some people are more interested in the FOP-TL label format for use as a reference prior to purchasing packaged food because it is easier to use (Azman and Sahak, 2014). Meanwhile, research in America has demonstrated that consumers prefer FOP (63\%) to Back of Pack (BOP) (42\%) labelling (Graham, Heidrick, \& Hodgin, 2015).

\section{Sodium labeling}

The public, despite the fact that packaged foods often have high sodium content (Watson et al, 2014), rarely treats sodium content as a concern. Sodium can trigger an increase in blood pressure that leads to hypertension. Indonesia has a high prevalence of hypertension, standing at $25.8 \%$, thus indicating the need to encourage people to read labels and choose food with lower sodium content (Ministry of Health, 2013). Researchers are therefore interested in conducting studies on the effect of FoP-TL labelling in patients with hypertension. 


\section{Methods}

\section{Study population}

This research is a quantitative study with a quasi-experimental study design. Two communities in Kramat Jati Village were chosen as the control and intervention groups based on the location of the remote area. The location of the region was determined to minimize the interaction between the two groups. The subjects in this study were selected using purposive sampling based on the characteristics of sex (female), age (30-59 years) and those with blood pressure in the hypertensive category (systolic $\geq 130 \mathrm{mmHg}$ or diastolic $\geq 80 \mathrm{mmHg}$ ) or with normal blood pressure but who took medication for hypertension.

\section{Design and Intervention}

The control group (10 subjects) was given nutritional value information labels, while the 11 subjects in the intervention group were given FoP-TL labels (Figure 1). The instruments used in this study were questionnaires, scales, a microtoise and a sphygmomanometer. The questionnaire was used to determine the characteristics of the subjects (age, education and income), their perceptions, attitudes and beliefs regarding nutrition, behaviour in relation to the reading of nutritional value information labels, nutrition and health-related knowledge, pre- and post-test understanding and acceptance of the labels. Scales were used to measure each subject's weight; the microtoise was used to measure their height, which is useful for determining the nutritional status of the subject, while the sphygmomanometer was used to determine the subjects' blood pressure.

The data collection began with age screening and blood pressure measurements. A subject's age was taken from their ID card, while a student from the Faculty of Nursing who is an expert in using the sphygmomanometer took the blood pressure readings. The subjects included in this study were those who had blood pressure in the hypertensive category (higher than 140/90 $\mathrm{mmHg}$ ) who had normal blood pressure but were taking hypertension medication.

Subjects who met the criteria were given a questionnaire to be completed independently. The questionnaire enquired as to the subjects' demography characteristics, whether they read labels containing information on nutritional value, knowledge, and understanding of the nutritional value information presented in labels (pre-test), anthropometry measurement data and blood pressure. Questions on the understanding of labels for nutritional value information were answered with the help of a dummy example of food and beverage packaging developed by the researchers. The enumerator provided assistance with the questionnaire by providing an explanation in the event that an element was not understood by the subject, in addition to checking the completeness of the answers to the questions. After having completed the questionnaire, the subjects were provided with an explanation of hypertension, including its causes, symptoms and classification, along with the types of food to either consume or avoid.

One week later, the participants were provided with an educational booklet containing information on nutritional value or FoP-TL labelling (according to the control and intervention groups). The contents were also explained to the respondents orally prior to them being given a copy of the booklet. One week after being given this material, namely in the fourth week, the post-test similar with the pre-test 
was conducted by distributing questionnaires to the subject in order to elicit their acceptance and understanding after one week of treatment. The behavior of reading food labels was categorized as either obedient or disobedient. The subjects were said to be obedient if they answered 'always' and 'often', and categorized as disobedient if they provided the answers 'sometimes', 'rarely' and 'never' to questions related to their habit of reading the different components of food labels. The respondents' understanding was assessed based on their answers to 16 questions and was categorized as less again need different labels if they had $\leq 60 \%$ correct answers, and good if they had $>60 \%$ correct answers. The ability receiving nutritional value information labels and FoP-TL labels was determined based on several aspects, including the preference for label design (4 questions), attractiveness (4 questions) and cognitive workload perception (5 questions). Each question was awarded a value according to the answer given, namely strongly agree $=5$; agree $=4$; normal $=3$; disagree $=2$; and strongly disagree $=$ 1.

\section{Results}

The demographic characteristics, BMI, blood pressure and level of knowledge were similar for both the intervention and control groups except that the control group had a significant higher income than the intervention group (Table 1). The components of the food labels most frequently observed by the subjects were the date of expiration (control group $81.8 \%$ and intervention group 100\%). Subject compliance in reading information labels on nutritional value was low for both the control $(36.4 \%)$ and intervention groups (50.0\%) as shown in Table 2.

Table 1. Characteristic of control and intervention groups

\begin{tabular}{|c|c|c|c|c|}
\hline \multirow{2}{*}{ Variabel } & Control $(\mathrm{n}=11)$ & Intervention $(\mathrm{n}=10)$ & \multirow{2}{*}{$95 \% \mathrm{CI}$} & \multirow{2}{*}{$\mathrm{p}$} \\
\hline & $\mathrm{n}(\%)$ & $\mathrm{n}(\%)$ & & \\
\hline \multicolumn{5}{|l|}{ Age (years old): } \\
\hline $30-45$ & $2(18.2)$ & $3(30.0)$ & \multirow[t]{2}{*}{$(0.25-14.88)$} & \multirow[t]{2}{*}{0.52} \\
\hline $46-59$ & $8(81.8)$ & $7(70.0)$ & & \\
\hline \multicolumn{5}{|l|}{ Last education: } \\
\hline $\begin{array}{l}\text { Less than senior high } \\
\text { school }\end{array}$ & $5(45.5)$ & $3(30.0)$ & \multirow{2}{*}{$(0.85-3.10)$} & \multirow{2}{*}{0.46} \\
\hline $\begin{array}{l}\text { More than senior high } \\
\text { school }\end{array}$ & $6(54.5)$ & $7(70.0)$ & & \\
\hline \multicolumn{5}{|l|}{ Monthly income (IDR): } \\
\hline Less than 3.,00,000 & $10(90.9)$ & $3(30.0)$ & \multirow[t]{2}{*}{$(0.004-0.502)$} & \multirow{2}{*}{$0.008 *$} \\
\hline $\begin{array}{l}\text { More than equal to } \\
3,000,000\end{array}$ & $1 \quad(9.1)$ & $7(70.0)$ & & \\
\hline \multicolumn{5}{|l|}{$\begin{array}{l}\text { BMI (Body Mass } \\
\text { Index) }\end{array}$} \\
\hline $\begin{array}{l}\text { Normal status (18.5- } \\
24.9)\end{array}$ & $3(27.3)$ & $5(50.0)$ & \multirow[t]{2}{*}{$(0.434-16.39)$} & \multirow[t]{2}{*}{0.38} \\
\hline Obesity $(>=25.0)$ & $8(72.7)$ & $5(50.0)$ & & \\
\hline \multicolumn{5}{|l|}{ Blood pressure (mmHg): } \\
\hline \multicolumn{5}{|l|}{ Sistolic: } \\
\hline$<140$ & $5(45.5)$ & $3(30.0)$ & \multirow{2}{*}{$(0.08-3.10)$} & \multirow{2}{*}{0.65} \\
\hline$\geq 140$ & $6(54.5)$ & $7(70.7)$ & & \\
\hline
\end{tabular}


Diastolic:

\begin{tabular}{lllll}
$<89$ & $1(9.1)$ & $2(20.0)$ & $(0.19-32.80)$ & 0.58 \\
$\geq 90$ & $10(90.9)$ & $8(80.0)$ & & \\
\hline $\begin{array}{l}\text { Nutrition label } \\
\text { knowledge level }\end{array}$ & & & & \\
Low $\quad(\leq 58.7)$ & $6(54.5)$ & $5(50.0)$ & & \\
Adequate $(>58.7)$ & $5(45.5)$ & $5(50.0)$ & \\
$* 0.05$ & & &
\end{tabular}

Table 2. Food label reading practices at both groups at the beginning of study

\begin{tabular}{llll}
\hline \multirow{2}{*}{ Label component } & Compliance level & \multicolumn{1}{l}{ Control } & Intervention \\
\cline { 3 - 4 } Serving portion information & Obey & $\mathrm{n}(\%)$ & $\mathrm{n}(\%)$ \\
\cline { 2 - 4 } & Did not obey & $6(45.5)$ & $5(50.0)$ \\
\hline \multirow{2}{*}{ Brand's name } & Obey & $3(27.3)$ & $3(30.0)$ \\
\cline { 2 - 4 } & Did not obey & $8(72.7)$ & $7(70.0)$ \\
\hline Nutrition information label & Obey & $4(36.4)$ & $5(50.0)$ \\
\cline { 2 - 4 } & Did not obey & $7(63.6)$ & $5(50.0)$ \\
\hline Ingredient's information & Obey & $2(18.2)$ & $4(40.0)$ \\
\cline { 2 - 4 } & Did not obey & $9(81.8)$ & $6(60.0)$ \\
\hline
\end{tabular}

There was a significant difference in the average scores of the two groups with regard to the component of reading behaviour of nutritional value information labels. Intervention group was more likely to read the nutritional value information at the end of study. Both the control and intervention subjects increased their understanding of nutritional labels between the pre and post test. There was significant difference of understanding score at post-study as seen in Table 3. The subjects of intervention group displayed a greater score increase (34.37 points) compared to those in the control group (22.15 points) at the end of study. The similar description was also showed in Table 4 in which the intervention group had the mean score of nutrition labels acceptance was bigger than the control group. Understanding and acceptance of nutrition labels had significant difference in the two groups after the study.

Table 3. Mean score of nutrition labels understanding

\begin{tabular}{llllll}
\hline \multirow{2}{*}{ Group } & \multicolumn{2}{l}{ Change $(\Delta)$} & 95\% CI & p value \\
\cline { 2 - 4 } & Min & Max & Mean & \\
\hline Control & 00.00 & 43.75 & 22.15 & $26.76-0.169$ & $* 0.047$ \\
Intervention & 18.75 & 56.25 & 34.37 & & \\
\hline
\end{tabular}

$* \mathrm{p}<0.05$ 
Table 4. Mean score of nutrition labels acceptance

\begin{tabular}{|c|c|c|c|c|c|}
\hline \multirow{2}{*}{ Group } & \multicolumn{3}{|c|}{ Change $(\Delta)$} & \multirow{2}{*}{$95 \% \mathrm{CI}$} & \multirow{2}{*}{$\mathrm{p}$-value } \\
\hline & Min & Max & Mean + SD & & \\
\hline Control & 38.00 & 59.00 & $47.71+7.00$ & $14.60-1.34$ & \multirow{2}{*}{$* 0.02 *$} \\
\hline Intervention & 41.00 & 63.00 & +7.51 & & \\
\hline
\end{tabular}

$* \mathrm{p}<0.05$

\section{Discussion}

A better understanding of the intervention group shows that FoP-TL labelling can help the community to identify the ingredients in packaged foods and thus select healthier foods. This is in line with research conducted by Findling et al. (2018) on female subjects in which it was shown that FoP-TL labelling can improve the understanding and ability to choose between two food products with better nutritional quality. In addition, FoP-TL labelling can provide information pertaining to the levels (i.e. high, medium and low) of nutrients in food products. This research shows positive results with regard to the understanding of the subjects after being given FOP-TL labels, thus indicating that this type of nutrition labelling may be considered for further examination by The National Agency of Drug and Food Control of Republic of Indonesia (BPOM).

Acceptance was measured at the end of the study together with the post-test. Measurements were not taken at the beginning due to the unfamiliarity of the subjects with FoP-TL labels, which meant it was not possible to determine the acceptability prior to the intervention being administered. The acceptance of the subjects in the intervention group of the FoP-TL labelling was better than that for the nutritional value information label.. This finding is consistent with that from a study conducted by Gorton, et al. (2008) in 25 New Zealand supermarkets, which stated that FOP-TL labelling is preferred by consumers relative to nutritional value information labels in both high- and low-income groups. This receiving power what is receiving power? is very important because it can affect consumers' habit of reading nutrition labels, which will also impact on their decision of whether or not to buy a product. Consumers will pay attention to the information contained in the label and will proceed to understand and store this information prior to making a purchase decision (Miller and Cassady, 2015). The study shows that the subjects in the intervention group (FoP-TL) were able to answer questions correctly concerning which products were healthier. This finding is in line with the research of Ducrot et al (2015) showed that FoP-TL label can improve subjects' ability to choose healthier products compared to labels without a FoP label. The results of research by McLean et al (2012) also demonstrated that subjects were able to compare products with high and low sodium contents using a FoP-TL label that included less in the way of numerical information and was more visually interesting in terms of the inclusion of colour. FoP-TL labels tend to be simpler, easier for consumers to use and more accurate when looking to make healthier product choices from a range of different product options (Me'jean et al, 2012).

FoP-TL labels are preferred because they tend to be simpler in comparison to nutritional value information labels. Nonetheless, the FSA has recommended the combination of a colour-based classification of nutrient content (high, medium and low) with a percentage of RDA figure as the most effective format (Night et al, 2009). Grunert and Wills (2007), in their review, also stated that although people tend to like the easy label format, they also want to know more about what the 
colours mean that are used to classify the nutrient content of different types of food and drink. Indeed, it is this that underlies the usage of the FOP format with colour to communicate the classification of the energy, sugar, salt, total fat and saturated fat content, so that people who read this type of label can quickly understand the ingredients without any loss of important information about the content.

\section{Conclusion}

After the study, the intervention group had a higher level of understanding and acceptance of nutrition labels than the control group. The FOP-TL label is effectively able to improve understanding and be well received by the community compared to the nutritional value information label. This research on FOP-TL labelling may be used as the basis for a study by The National Agency of Drug and Food Control of Republic of Indonesia (BPOM) to begin regulating and implementing this type of system in Indonesia. In addition, research on the influence of FOP-TL labels is still very rare in Indonesia, this is the point especially with regard to studies looking at the factors that affect understanding and acceptability. This indicates that further research is needed with larger samples and in reference to regulations on food and nutrition labelling systems based on BPOM laws and regulations.

\section{References}

Andrews, J. C., Burton, S., \& Kees, J. (2011). Is Simpler Always Better? Consumer Evaluations of FrontOf-Package Nutrition Symbols. Journal of Public Policy \& Marketing, 30(2), 175-190.

Azman, N., \& Sahak, S. Z. (2014). Nutritional Label and Consumer Buying Decision. Procedia - Social and Behavioral Sciences, 130, 490-498.

Baliwati, Y. F., Khomsan, A., \& Dwiriani, M. C. (2004). Pengantar Pangan dan Gizi. Depok: Penebar Swadaya.

BPKN, B. P. (2007). Hasil Kajian BPKN di Bidang Pangan Terkait Perlindungan Konsumen. Jakarta. Retrieved Maret 2018, from http://ditjenspk.kemendag.go.id/files/pdf/2013/06/04/hasil-kajian-badanperlindungan-konsumen-nasional-bpkn-di-bidang-pangan-terkait-perlindungan-konsumen-id01370355071.pdf

Campos, S., Doxey, J., \& Hammond, D. (2011). Nutrition labels on pre-packaged foods: a systematic review. Nutrition labels on pre-packaged foods: a systematic review, 14(8), 1496-1506.

Deloitte. (2016). Deloitte Consumer Insights The Evolution of The Indonesian Consumer. UK: Deloitte Southeast Asia.

Ducrot, P., Méjean, C., Julia, C., Kesse-Guyot, E., Touvier, M., Fezeu, L., . . Péneau, S. (2015). Effectiveness of Front-Of-Pack Nutrition Labels in French Adults: Results from the NutriNet-Santé Cohort Study. Plos One, 1-15.

Edge, M. S., Toner, C., Kapsak, W. R., \& Geiger, C. J. (2014). The Impact of Variations in Fact-Based Front-of-Package Nutrition Labeling System on Consumer Comprehension. Journal of The Academy Nutrition and Dietetics, 114(6), 845-854.

FDA, F. a. (2016). Sodium in Your Diet: Use the Nutrition Facts Label and Reduce Your Intake. Retrieved Maret 3, 2018, from http://www.fda.gov/educationresourcelibrary

Feunekes, G. I., Gortemakera, I. A., Willemsa, A. A., Liona, R., \& Kommer, M. v. (2008). Front-of-pack nutrition labelling: Testing effectiveness of different nutrition labelling formats front-of-pack in four European countries. Appetite, 50, 57-70.

Findling, M. T., Werth, P. M., Musicus, A. A., Bragg, M. A., Graham, D. J., Elbel, B., \& Roberto, C. A. (2018). Comparison five front-of-package nutrition labels infuence on consumers perception and purchase intentions. Preventive Medicine, 106, 114-121. 
Gorton, D., Mhurchu, C. N., Chen, M.-h., \& Dixon, R. (2008). Nutrition Labels: A Survey of Use, Understanding and Prefences Among Ethnically Diverse Shoppers in New Zealand. Public Health Nutrition, 12(9), 1359-1365.

Graham, D. J., Heidrick, C., \& Hodgin, K. (2015). Nutrition Label Viewing during a Food Selection Task: Front-of-Package Labels vs Nutrition Facts Labels. Journal of The Academy of Nutrition and Dietetics, 115(10), 1636-1646.

Grunert, K. G., \& Wills, J. M. (2007). A review of European research on consumer response to nutrition information on food labels. J Public Health, 15, 385-399.

Gupta, K. \&. (2016). Use and influence of nutrition labelling: an emerging market experience. Nutrition \& Food Science, 46(3), 441-456.

Gupta, K., \& Dharni, K. (2016). Use and influence of nutrition labelling: an emerging market experience. Nutrition \& Food Science, 46(3), 441-456.

Helfer, P., \& Shultz, T. R. (2014). The effects of nutrition labeling on consumer food choice: a psychological experiment and computational model. ANNALS OF THE NEW YORK ACADEMY OF SCIENCES, 1331(1), 174-185.

Hodgkins, C. E., Raats, M. M., Fife-Schaw, C., Peacock, M., Gro"ppel-Klein, A., Koenigstorfer, J., . . . Yaprak Gulcan4, Y. K. (2015). Guiding healthier food choice: systematic comparison of four front-of-pack labelling system and their effect on judgements of products healthiness. British Journal od Nutrition, 113, 1652-1663.

Jacobs, S. A., Beer, H. d., \& Larney, M. (2010). Adult Consumers' Understanding and Use of Information on Food Labels: A Study Among Consumers Living in the Potchefstroom and Klerksdorp Regions, South Africa. Public Health Nutrition, 14(3), 510-522.

Julia, C., Kesse-Guyot, E., Ducrot, P., Péneau, S., Touvier, M., Méjean, C., \& Hercberg, S. (2015). Performance of a five category front-of-pack labelling system - the 5-colour nutrition label- to differentiate nutritional quality of breakfast cereals in France. BMC Public Health, 15(1), 179.

Kees, J., Royne, M. B., \& Cho, Y.-N. (2014). Regulating Front-of-Package Nutrition Information Disclosures: A Test of Industry Self-Regulation vs. Other Popular Options. The Journal Of Consumers Affairs, 3(4), 300-306.

Knox, B., Hill, D., \& Hamilton, J. (2001). Consumers talking about reduced fat foods. Food Industry Journal, 4(1), 12-25.

Liu, R., Hoefkens, C., \& Verbeke, W. (2015). Chinese consumers' understanding and use of a food nutrition label. Food Quality and Preference, 41, 103-111.

Malam, S., Clegg, S., Kirwan, S., McGinigal, S., \& Research, B. S. (2009, May). Comprehension and use of UK nutrition signpost labelling schemes. Retrieved Juni 25, 2018, from http://citeseerx.ist.psu.edu/viewdoc/download?doi=10.1.1.610.1749\&rep=rep1\&type=pdf

McLean, R., Hoek, J., \& Hedderley, D. (2012). Effects of alternative label formats on choice of high- and low-sodium products in a New Zealand population sample. Public Health Nutrition, 15(5), 783-791.

Me'jean, C., Macouillard, P., Pe'neau, S., Hercberg, S., \& Castebon, K. (2012). Perception of front-ofpack labels according to social characteristics, nutritional knowledge and food purchasing habits. Public Health Nutrition, 16(3), 392-402.

Me'jean, C., Macouillard, P., Pe'neau, S., Lassale, C., Hercberg, S., \& Castetbon, K. (2014). Association of Perception of Front-of-Pack Labels with Dietary Lifestyle and Health Characteristics. Plos One, 9(3), e90971.

Miller, L. M., \& Cassady, D. L. (2015). The effects of nutrition knowledge on food label use. Appetite, 92, 207-216.

Mohan, S., Campbell, N. R., \& Willis, K. (2009). Effective population-wide public health interventions to promote sodium reduction. CMAJ, 181(9), 605-609.

Nelson, D., Graham, D., \& Harnack, L. (2014). An Objective Measure of Nutrition Facts Panel Usage. Journal of Nutrition Education and Behavior, 46(6), 589-593. 
Palupi, I. R., Naomi, N. D., \& Susilo2, J. (2017). Penggunaan Label Gizi dan Konsumsi Makanan Kemasan pada Anggota Persatuan Diabetisi Indonesia. Kesmas: Jurnal Kesehatan Masyarakat, 11(1), 1-8.

Post, R. E., Iii, A. G., Diaz, V. A., Matheson, E. M., \& Everett, C. J. (2010). Use of The Nutrition Fact Label in Chronic Disease Management: Result from the National Health and Nutrition Examination Survey. Journal of the American Dietetic Association, 110(4), 628-632.

Ranilovic, J., \& Baric, I. C. (2011). Difference Between Younger and Older Population in Nutriiton Label Reading Habits. British Food Journal, 113(1), 109-121.

Regan, Á., Shan, C. L., Wall, P., \& McConnon, Á. (2016). Perspectives of the public on reducing population salt intake in Ireland. Public Health Nutrition, 19(7), 1327-1335.

Roberto, C., \& Khandpur, N. (2014). Improving the design of nutrition labels to promote healthier food choice and reasonable portion size. International Journal of Obesity, 38, 525-533.

Themba, G., \& Tanjo, J. (2013). Consumer Awareness and Usage of Nutrition Information in Botswana. Business and Management Horizons, 1(1), 44.

Vyth, E. L., Steenhuis, I. H., Brandt, H. E., Roodenburg, A. J., Brug, J., \& Seidell, J. C. (2012). Methodological quality of front-of-pack labeling studies: a review plus identification of research challenges. Nutrition Reviews, 70(12), 709-720.

Watson, W. L., Kelly, B., Hector, D., Hughes, C., King, L., \& Crawford, J. (2014). Can front-of-pack labelling schemes guide healthier food choices? Australian Shoppers' Responses to Seven Labelling Formats. Appetite, 72, 90-97.

Williams, S. L., \& Mummery, K. W. (2012). Characteristics of consumers using 'better for you' front-ofpack food labelling schemes - an example from the Australian Heart Foundation Tick. Public Health Nutrition, 16(12), 2265-2272.

Zahara, S., \& Triyanti. (2009). Kepatuhan Membaca Label Informasi Zat Gizi di Kalangan Mahasiswa. Kesmas: National Public Health Journal, 4(2), 78-83. 